\title{
STATUTE OF LIMITATIONS FOR PASSENGER CLAIMS RESULTING FROM THE EUROPEAN UNION REGULATIONS
}

DATA PRZESŁANIA: 03.07.2018, DATA AKCEPTACJI: 17.08.2018, JEL CODES: K12, K22

\section{Dorota Ambrożuk}

Faculty of Management and Economics of Services, University of Szczecin dorota.ambrozuk@wzieu.pl

Contract of carriage of persons is currently governed by European Union, national and international law. European Union regulations related thereto apply to both national and international carriage operations. The article analyses the problems related to the determination the statute of limitations for passenger claims resulting from the European Union regulations. With the exception of the Regulations No. 1371/2007 and 392/2009, these legal acts do not provide for the statute of limitations. This raises the question of which provisions should then be applied. The aim of the article is to resolve this issue in relation to both domestic and international carriage.

KEYWORDS

statute of limitations, prescription periods, time-bar, carriage of passengers, recovery of passengers claims

\section{INTRODUCTION}

Recognising that the provisions of international conventions ${ }^{1}$ and the national legislation of the EU Member States do not sufficiently protect the interests of the passengers, the EU bodies have issued a number of regulations concerning the particular modes of transport, i.e.:

\footnotetext{
1 Poland ratified the following conventions: Convention concerning International Carriage by Rail (COTIF) of 9 May 1980 (Journal of Laws of 1985 No. 34, item 158) as amended by the Vilnius Protocol of 3 June 1999 (Journal of Laws of 2007 No. 100, item 674), Appendix A. Uniform Rules concerning the Contract of International Carriage of Passengers by Rail (CIV); two air flight conventions: the so-called Warsaw Convention, i.e. the Convention for the Unification of Certain Rules Relating to International Carriage by Air of 12 October 1929 (Journal of Laws of 1933 No. 8, item 49) as amended by the Hague Protocol of 28 September 1955 (Journal of Laws of 1963 No. 33, item 189), supplemented by the Convention for the Unification of Certain Rules Relating to International Carriage by Air Performed by an Entity other than the Carrier under the Contract of 18 September 1961 (Journal of Laws of 1965 No. 25, item 167) and the so-called Montreal Convention, i.e. the Convention for the Unification of Certain Rules for International Carriage by Air of 28 May 1999 (Journal of Laws of 2007 No. 37,
} 
a) Regulation (EC) No. 2027/97 of the Council of 9 October 1997 on air carrier liability in respect of the carriage of passengers and their baggage by air (Official Journal of the European Union 1997 L 285/1) as amended by Regulation (EC) No. 889/2002 of the European Parliament and of the Council of 13 May 2002 (Official Journal of the European Union 2002 L 140/2, Polish Special Edition 2004, Chapter 7, Volume 6, p. 246);

b) Regulation (EC) No. 261/2004 of the European Parliament and of the Council of 11 February 2004 establishing common rules on compensation and assistance to passengers in the event of denied boarding and of cancellation or long delay of flights, and repealing Regulation (EEC) No. 295/91 (Official Journal of the European Union 2004 L 46/1);

c) Regulation (EC) No. 1107/2006 of the European Parliament and of the Council of 5 July 2006 concerning the rights of disabled persons and persons with reduced mobility when travelling by air (Official Journal of the European Union 2006 L 204/1);

d) Regulation (EC) No. 1371/2007 of the European Parliament and of the Council of 23 October 2007 on rail passengers' rights and obligations (Official Journal of the European Union 2007 L 315/14);

e) Regulation (EC) No. 392/2009 of the European Parliament and of the Council of 23 April 2009 on the liability of carriers of passengers by sea in the event of accidents (Official Journal of the European Union 2009 L 131/24);

f) Regulation (EC) No. 1177/2010 of the European Parliament and of the Council of 24 November 2009 concerning the rights of passengers when travelling by sea and inland waterway and amending Regulation (EC) No. 2006/2004 (Official Journal of the European Union 2010 L 334/1);

g) Regulation (EC) No. 181/2011 of the European Parliament and of the Council of 16 February 2011 concerning the rights of passengers in bus and coach transport and amending Regulation (EC) No. 2006/2004 (Official Journal of the European Union 2011 L 55/1).

Not only did the abovementioned atcs increase the passenger protection in situations already governed by the existing legislation, but also in situations which were not regulated before. ${ }^{2}$ The regulations apply to both international carriage, including carriage regulated by international conventions, and national carriage governed by the internal regulations of each individual EU Member State. In relation to Poland, the most crucial rules related thereto are included in the Carriage Law Act of 15 November 1984 (consolidated version published in the Journal of Laws of 2017, item 1983) and in the Civil Code of 23 April 1964 (consolidated version published in the Journal of Laws of 2018, item 1025). Thus, a multicentric system for regulating the contract of carriage of passengers has been created. ${ }^{3}$

\footnotetext{
item 235); the Athens Convention relating to the Carriage of Passengers and their Luggage by Sea of 13 December 1974 (Journal of Laws of 1987 No. 18, item 108) as amended by the Protocol to the Athens Convention of 19 November 1976 (Journal of Laws of 1994 No. 99, item 479). Poland has not ratified the Protocol of 2002 to the Athens Convention which came into force on 23 April 2014. The EU acceded to this Protocol by virtue of the two decisions of the Council of 12 December 2011 (Official Journal of the European Union L8/1 as amended and Official Journal of the European E L 8/13 as amended). Pursuant to Article 216(2) of the Treaty on the Functioning of the European Union (consolidated version published in the Official Journal of the European 2012 C326/1), Poland is obliged to apply the Protocol of 2002 with respect to the EU carriage.

2 For the purpose and scope of the protection, see (Gospodarek, 2011, pp. 55-68; Ambrożuk, 2014, pp. 11-24).

3 For the multicentricity of the regulation, see more (Łętowska, 2005, pp. 3-10; Wesołowski, 2016, pp. 201-215 and Kotowski, 2015, pp. 101-122).
} 
It has to be, however, noted that EU regulations - with certain exceptions - do not provide for the statute of limitations. The prescription periods are treated by EU bodies as rules of a procedural nature, which remain within the competence of EU Member States (vide: resolution of the Supreme Court of 17 March 2017, III CZP 111/16; www.sn.pl/sites/orzecznictwo/orzeczenia3/iii\%20czp\%20111-16.pdf, access: 15 May 2018). Considering the above, the question therefore arises: what rules should then be applied? This refers both to claims which are provided for in the international conventions and are only modified or supplemented by the EU regulations (e.g. compensation in respect of death of or personal injury to passengers) and to claims which are based solely on EU regulations (the so-called flat-rate compensation).

The aim of this elaboration is to provide the answer to the above question. However, the limited volume of the article allows only to outline the preliminary findings related thereto.

\section{STATUTE OF LIMITATIONS FOR CLAIMS RESULTING FROM THE AVIATION REGULATIONS}

The aviation law provide for the claims that are based on the aviation conventions (the Warsaw Convention and the Montreal Convention), EU regulations (e.g. claims resulting from the violation of life or health of a passenger), as well as claims for which the basis is derived solely from the EU regulation (e.g. a claim for a flat-rate compensation in the event of a cancellation of a flight). However, the regulations do not provide for a statute of limitations for these claims. The Court of Justice of the European Union (hereinafter referred to as the CJEU or the Court) has already expressed its view in this matter in terms of both abovementioned types of claims.

In the judgment of 22 October 2009 in the case C-301/08 Bogiatzi (ECLI:EU:C:2009:649), the Court dealt with a statute of limitation for a claim that may be included in the former group, namely the prescription period for a claim for compensation in respect of an accident sustained by a passenger, based on the Regulation No. 2027/97. The Court concluded that the regulation must be interpreted as not precluding the application of the two-year limitation period provided for in the Article 29 of the Warsaw Convention to such a claim. The Court's reasoning was based on a purposeful interpretation. The Court stated that the purpose of Regulation No. 2027/97 is to increase the level of protection of passengers by replacing certain provisions of the Warsaw Convention with legal solutions provided for in the Regulation. This does not mean, however, that the application of other provisions of the Convention, including the rules for determining air carrier liability under the Article 29 of the Warsaw Convention, should therefore be excluded.

In the judgment of 22 November 2012 in the case C-139/11 Moré (ECLI:EU:C:2012:741), the Court addressed the issue of the statute of limitation for claims included in the second group. In that judgment, the Court ruled on the prescription period for claims for the flat-rate compensation provided for by the Regulation No. 261/2004. In view of the fact that the abovementioned compensation falls outside the scope of the Warsaw and Montreal Conventions, the Court stated that the limitation period for bringing an action should be determined in accordance with the rules on limitation of claims laid down by each Member State. At the same time, the Court emphasised that such a position does not contradict the judgment in the Case C-301/08 Bogiatzi, cited above, due to a different basis for pursuing the claim (there, the claim was provided for both in the Regulation and in the Convention). 
In the case of air carriage, the Court therefore concluded that the statute of limitations laid down in the air conventions should apply to claims based on both the conventions and the regulations. In the case of claims which are exclusively governed by the regulations, the appropriate limitation period should be determined in accordance with the rules of applicable national law. If the national law is Polish law, then - as the Supreme Court properly assumed in the resolution of 17 March 2017 referred to above in the case III CZP 111/16 - the one-year limitation period resulting from the Article 778 of the Civil Code should then be applied. However, this issue aroused divergences both in the case law $^{5}$ and in the literature referring to this subject. ${ }^{6}$

The abovementioned solutions should also be applied when establishing the statute of limitations for claims of disabled persons or persons with reduced mobility against air carriers under the Regulation No. 1107/2006. This means that if the regulation provides for claims that may be brought by such passengers and, at the same time, such claims are also provided for by the Montreal Convention (e.g. compensation for lost or damaged wheelchairs or other mobility equipment to be treated as luggage), the two-year limitation period under Article 35 of the Montreal Convention shall apply. Statute of limitations for other claims ought to be determined in accordance with the provisions of the national law.

\section{STATUTE OF LIMITATIONS FOR CLAIMS RESULTING FROM THE RAILWAY REGULATION}

Likewise, in the case of rail transport there are claims based on the regulation, the convention and only the regulation (i.e. Regulation No. 1371/2007 and CIV Convention). However, unlike the aviation law, this regulation provides for the rules on statute of limitations. Indeed, Appendix I to the Regulation No. 1371/2007 is an extract from the CIV Convention, including the Article 60 of the CIV (with the exception of paragraphs 4 and 5). This provision provides for three periods of limitation: a three-year period for claims for compensation in respect of death of, or personal injury to, passengers (Article 60(1)), a one-year period for other claims based on a transport contract, and a two-year period for claims for damage resulting from an act or omission committed either with the intent to cause such loss or damage, or recklessly and with knowledge that such loss or damage would probably result (Article 60(2)).

It would appear, therefore, that the reference in Article 60(2) of Annex I to Regulation No. $1371 / 2007$ to 'other claims arising from the contract of carriage', the limitation as referred to therein, will be applicable to all claims, other than those referred to in Article 60(1), arising from

\footnotetext{
4 See also Ambrożuk (2017, pp. 63-71).

5 The courts applied: the ten-year limitation period provided for in the Article 18 of the Polish Code of Civil Procedure [District Court for the capital city of Warsaw in the judgment of 14 March 2016, case ref. No.: II C 2709/15]; the two-year limitation period, provided for in the Article 35 of the Montreal Convention [District Court for the capital city of Warsaw in the judgment of 31 July 2015, case ref. No.: II C 2491/13]; the one-year limitation period, provided for in Article 778 of the Civil Code [Regional Court in Szczecin in the judgment of 25 March 2014,case ref. No.: II Ca 1299/13, upholding the judgment of the District Court Szczecin-Centrum in Szczecin of 30 July 2013, case ref. No.: III C 365/13].

6 The one-year limitation period under the Article 778 of the Civil Code has been advocated by (Ambrożuk, Wesołowski, in press) and (Kasprzyk, Konert, 2017, pp. 55-72); ten-year limitation period under the Article 118 of the Civil Code has been advocated by (Ratnicki-Kiczka, 2017, pp. 149).
} 
the carriage to which that regulation applies. ${ }^{7}$ However, the matter is not so obvious. In fact, the reference to the Article 60 in Title VI (Enforcement) of the Annex I does not refer to all claims for damages provided for by the Regulation No. 1371/2007, but only to those set out in Chapter III of that act (Liability of railway undertakings for passengers and their luggage, Articles 11 to 14). Article 15 of the Regulation 1371/2007 (Liability for delays, missed connections and cancellations), which is included in the Chapter IV (Delays, missed connections and cancellations of trains), also refers to the Annex I, but only to the provisions of the Chapter II of Title IV thereof, which does not contain Article 60 referring to the limitation and prescription periods. Therefore, the Regulation No. 1371/2007 does not set time limits for claims for delay, loss and cancellation of a train. The failure to include a reference to Annex I, Title VI, for these claims does not, however, imply the possibility of accepting the CJEU's solution for claims under the aviation regulations. This is determined by the different scope of the statute of limitations contained in the Article 60(2) of the CIV as compared to the Article 35 of the Montreal Convention. It follows from the wording of the Article 60(2) that it applies to all claims arising under a contract governed by the CIV Convention. This means that if a carriage, to which the Regulation No. 1371/2007 applies, is international in nature, the provisions of the CIV Convention and Article 60(2) thereof should apply to matters not covered by the regulation. On the other hand, if a carriage may be regarded international and EU at the same time, but the CIV Convention does not apply to it, ${ }^{8}$ the limitation period should be determined by the rules provided for by the applicable national law.

The provisions of national law should also be applied to national carriage operations, which fall within the scope of the Regulation No. 1371/2007, in respect of all claims for compensation under that regulation, with the exception of claims for compensation for death of, or personal injury to, passengers and their luggage (which are governed, as has already been mentioned above, by the statute of limitations laid down in the Article 60 of the Annex I to that regulation). If the national law is Polish law, the one-year limitation period under the Article 778 of the Civil Code shall apply. Although the contract for the carriage of passengers in national transport is governed by both the Regulation No. 1371/2007 and the Transport Law Act, which also applies to the rail carriage (it regulates the carriage in all modes of transport, except maritime, air and horse carriage - vide: Article 1(1)), the provision of the Article 77 thereof in such a situation cannot be applied. It follows from the wording of this article that the one-year limitation period shall apply

\footnotetext{
The provisions of the Regulation No. 1371/2006, subject to the exclusions provided for therein, apply throughout the EU to all journeys and rail services provided by one or more railway undertakings duly authorised by the Directive 2004/49/EC of the European Parliament and of the Council of 29 April 2004 on safety on the Community's railways and amending Council Directive 95/18/EC on the licensing of railway undertakings and Directive 2001/14/EC on the allocation of railway infrastructure capacity and the levying of charges for the use of railway infrastructure and safety certification (Railway Safety Directive, published in the Official Journal of the European Union L 2004.164, pp. 44-113, Special edition in Polish: Chapter 7, Volume 8, pp. 227-250).

8 CIV convention shall not apply to carriage performed between stations situated on the territory of neighbouring states, when the infrastructure of these stations is managed by one or more infrastructure managers subject to only one of those states. The EU Member States may conclude agreements which provide for derogations from the rules provided for by the CIV convention for carriage performed exclusively between two stations on either side of the frontier, when there is no other station between them. In addition, for carriage performed between two EU Member States, passing through a state which is not a EU Member State, the states concerned may conclude agreements which derogate from the CIV rules.
} 
to claims pursued under this act or under acts adopted in implementation thereof. Therefore, in accordance with Article 90 of the Transport Law Act, the provisions of the Civil Code, more particularly the provision of the Article 778, are applied in a subsidiary way.

\section{STATUTE OF LIMITATIONS FOR CLAIMS UNDER REGULATIONS RELATING TO OTHER MODES OF TRANSPORT}

In the case of Regulation No. 392/2009 on the liability of carriers of passengers by sea in the event of accidents, although the technique of an annex extracted from the convention has been used in this case as well, the matter of the determination of the statute of limitations is different. The regulation covers claims which are also governed by the Athens Convention as amended by the 2002 Protocol, i.e. claims for damages in respect of the death of or personal injury to a passenger or for the loss of or damage to luggage. According to Article 16(1) of the Athens Convention, which constitutes the Annex I to the regulation, such claims are a subject to a twoyear limitation period. This regulation shall apply to any international carriage and to carriage by sea within a single Member State on board ships of classes A and B. In addition, Member States may apply this regulation to all domestic sea-going voyages.

Other regulations, like the aviation regulations, do not provide for any limitation periods. However, this does not mean that the position taken by the CJEU with regard to the air services may be applied to them.

Thus, claims resulting from the Regulation No. 1177/2010 are a subject to a two-year limitation period, but only in the case of carriage by sea. The provisions of the Maritime Code of 18 September 2001 (consolidated text published in the Journal of Laws of 2016, item 66, as amended) shall apply to the contract of carriage of passengers by sea in the scope not regulated by the provisions of Regulation No. 1177/2010 (Article $172 \$ 1$ a of the Maritime Code). At the same time, by virtue of the provision of the Article 186 of the Civil Code, the two-year limitation period applies to claims on grounds other than those provided for in the Athens Convention and the Regulation No. 392/2009.

With regard to the passenger claims under the Regulation No. 1177/2010 in relation to inland waterway carriage, as well as claims under the Regulation No. 181/2011 (concerning bus and coach transport), given the absence of similar provisions in the international conventions (Poland has not ratified the CMNI Convention - the Convention of 22 June 2001 on the Contract for the Carriage of Goods by Inland Waterway), the statute of limitations laid down in national law should apply. In the case of Polish law, the provision of the Article 778 of the Civil Code, which provides for a one-year limitation period, shall apply. As it has been indicated above, although the Transport Law Act applies to inland waterways transport as well as coach and bus transport, claims resulting from the aforementioned regulations are not included in the provisions of the Article 77 of the Transport Law. 


\section{CONCLUSION}

As can be inferred from the above, it may be difficult to define the rules applicable to the statutes of limitations for the passenger claims arising from the European Union regulations.

The position taken by the CJEU on the basis of the aviation regulations is not always adequate for other modes of transport. This is a consequence of the different way of regulation. Rail and maritime transport use the technique of incorporating the provisions of the transport conventions containing statute of limitations into the European Union regulations. Thus they regulate - although not fully - the limitation periods for claims resulting from the regulations. However, with regard to the inland waterway and coach and bus services carriage, there are no relevant conventional rules. This makes it necessary to apply national regulations. In all these cases, the issue of the statute of limitations should be assessed on the basis of the provisions of the Article 778 of the Civil Code. The exception is maritime carriage, where the provision of Article 186 of the Maritime Code applies.

\section{REFERENCES}

Ambrożuk, D. (2014). Kształtowanie się europejskiego prawa przewozu osób. In: T. Kocowski, K. Marak (ed.), Zmiany prawodawstwa gospodarczego w okresie transformacji ustrojowej w Polsce. Prace Naukowe Uniwersytetu Ekonomicznego we Wrocławiu, 362, 11-24. DOI: 10.15611/pn.2014.362.01.

Ambrożuk, D. (2017). Glosa do uchwały SN z 17.03.2017, III CZP 111/16. Problemy Transportu i Logistyki, 4, 63-71. DOI: 10.18276/ptl.2017.40-06/63-71.

Ambrożuk, D., Wesołowski, K. (in press). Terminy na dochodzenie zryczałtowanych odszkodowań należnych pasażerom na podstawie rozporządzenia (WE) nr 261/2004. In: P. Cybula (ed.), Prawne aspekty podróży i turystyki - historia i współczesność. Prace poświęcone pamięci Profesora Janusza Sondla. Kraków: Wyd. UJ.

Gospodarek, J. (2011). Cel i zakres ochrony konsumenta na rynku usług transportowych w świetle prawa Unii Europejskiej. Zeszyty Naukowe Uniwersytetu Szczecińskiego, 694, Problemy Zarządzania, Finansów i Marketingu, 22, 55-68.

Kasprzyk, P., Konert, A. (2017). Przedawnienie roszczeń odszkodowawczych za overbooking. Państwo i Prawo, 6, 55-72. Warszawa: Wolters Kluwer.

Kotowski, A. (2015). Zjawisko multicentryczności systemu prawa z perspektywy koncepcji integracyjnej. Studia Prawnicze. 4, 101-122.

Łętowska, E. (2005). Multicentryczność współczesnego systemu prawa i jej konsekwencje. Państwo i Prawo, 4, 3-10.

Ratnicki-Kiczka, P. (2017). Odszkodowania lotnicze na podstawie rozporządzenia (WE) Nr 261/2004 Parlamentu Europejskiego i Rady w orzecznictwie sądów polskich. In: D. Wetoszka (ed.), Prawo transportowe. Morze. Ląd. Powietrze (pp. 141-151). Warszawa: C.H. Beck.

Wesołowski, K. (2016). Multicentryczność regulacji usługi przewozu osób. Marketing i Zarządzanie, 1 (42), $201-215$. DOI: $10.18276 / \mathrm{miz} .2016 .42-14$. 
Przedawnienie roszczeń pasażerskich wynikających z rozporządzeń unijnych

\begin{tabular}{l|l} 
STRESZCZENIE & $\begin{array}{l}\text { Umowa przewozu osób jest obecnie normowana aktami prawa unijnego, krajowego i mię- } \\
\text { dzynarodowego. Przepisy unijne stosuje się zarówno do przewozów krajowych, jak i mię- } \\
\text { dzynarodowych. Artykuł poświęcony jest problemom związanym z ustaleniem terminów } \\
\text { przedawnienia roszczeń przysługujących pasażerom, wynikających z rozporządzeń unij- } \\
\text { nych. Rozporządzenia te, } \mathrm{z} \text { wyjątkiem rozporządzeń nr 1371/2007 i 392/2009, nie zawierają } \\
\text { przepisów dotyczących przedawnienia roszczeń. Powstaje zatem problem, jakie przepisy na- } \\
\text { leży wówczas stosować. Celem artykułu jest rozstrzygnięcie tej kwestii zarówno w odniesie- } \\
\text { niu do przewozów krajowych, jak i międzynarodowych. }\end{array}$ \\
StOWA KLUCZOWE & $\begin{array}{l}\text { przedawnienie, umowa przewozu osób, dochodzenie roszczeń pasażerskich }\end{array}$
\end{tabular} 


\section{PARAMOUNT CLAUSE IN THE INTERNATIONAL TRANSPORT OF GOODS BY ROAD AND RAIL}

DATA PRZESŁANIA: 25.07.2018, DATA AKCEPTACJI: 18.08.2018, JEL CODES: K12, K22

\section{Konrad Garnowski}

Wydział Zarządzania i Ekonomiki Usług, Uniwersytet Szczeciński konrad.garnowski@wzieu.pl

The paramount clause is the particular in the consignment note drawn during the performance of international carriage of goods by road and rail, according to which the carriage is subject to the provisions of applicable convention, notwithstanding any clause to the contrary. Inclusion of the entry is one of the carrier's obligations, which in practice is not always performed. In the article the author describes the consequences of the lack of such particular and indicates situations in which the carrier may be held liable for the damage caused by this omission. However, the author eventually presents the view that due to the serious evidential difficulties it would be unlikely to obtain damages for the failure to include the paramount clause.

\section{INTRODUCTION}

Provisions of international transport law regarding road and rail transport introduce the concept of the paramount clause. This clause is a statements included in the consignment note that the carriage is subject, notwithstanding any clause to the contrary, to the provisions of applicable convention. The requirement to include such particular in the consignment note can be found in Article $6(2)(\mathrm{k})$ of the CMR convention ${ }^{1}$ and Article $6 \$ 1(\mathrm{p})$ of the CIM convention. ${ }^{2}$ None of the acts expressly indicates that this clause is supposed to be included by the carrier, but there should be no doubt in this regard, since both of them stipulate that the carrier is the person liable

1 Convention on the Contract for the International Carriage of Goods by Road signed in Geneva on 19 may 1956.

2 Uniform Rules Concerning the Contract of International Carriage of Goods by Rail (CIM) - Appendix B to the Convention concerning International Carriage by Rail (COTIF) of 9 May 1980 as amended by the Protocol of Modification of 3 June 1999 (Vilnius). 